Journal of Comparative International Management

JCIM $\left.\right|_{\text {International Management }} ^{\text {Journal of Comparative }}$

\title{
The Role of Remittance-Induced Credit Expansion in a Short-Run Keynesian Macroeconomic Model
}

\section{Muhammad Rashid and Basu Sharma}

Volume 20, Number 1, 2017

URI: https://id.erudit.org/iderudit/1055448ar

DOI: https://doi.org/10.7202/1055448ar

See table of contents

Publisher(s)

Management Futures

ISSN

1481-0468 (print)

1718-0864 (digital)

Explore this journal

Cite this article

Rashid, M. \& Sharma, B. (2017). The Role of Remittance-Induced Credit Expansion in a Short-Run Keynesian Macroeconomic Model. Journal of Comparative International Management, 20(1).

https://doi.org/10.7202/1055448ar
Article abstract

This paper introduces a remittance-induced credit expansion in a static Keynesian macroeconomic model. A credit expansion in the monetary sector results in lowering the equilibrium level of interest rates, which in turn stimulates interest-sensitive consumption and investment. Secondly, the paper introduces a direct effect of remittances on investment. With the two extensions in a static Keynesian model of remittances, the paper derives the equilibrium level of national income and shows the effects of interactions of remittances with the monetary sector on national income. The results of the paper are illustrated numerically. 


\title{
The Role of Remittance-Induced Credit Expansion in a Short-Run Keynesian Macroeconomic Model
}

\author{
by
}

\author{
Muhammad Rashid \\ University of New Brunswick, Canada \\ Basu Sharma \\ University of New Brunswick, Canada
}

\begin{abstract}
This paper introduces a remittance-induced credit expansion in a static Keynesian macroeconomic model. A credit expansion in the monetary sector results in lowering the equilibrium level of interest rates, which in turn stimulates interestsensitive consumption and investment. Secondly, the paper introduces a direct effect of remittances on investment. With the two extensions in a static Keynesian model of remittances, the paper derives the equilibrium level of national income and shows the effects of interactions of remittances with the monetary sector on national income. The results of the paper are illustrated numerically.
\end{abstract}

\section{Introduction}

The World Bank report "Migration and Development Brief”, 2014, states that remittance flows to all developing countries were $\$ 50$ billion (US) in 2000 and that these flows rose to $\$ 450$ billion (US) by 2014 , representing an annual rate of increase of $17 \%$. The rapid increase in remittances resulted in remittances exceeding other sources of foreign exchange reserves in most of the recipient developing countries by 2014. As a source of external funding to developing countries, remittances have now become more dominant relative to other sources such as direct foreign investment, foreign aid, and foreign credit. The ratio of remittances to GDP has also risen sharply, especially in small developing countries such as Kyrqz Republic, Tajikistan, Tonga, Moldova, Samoa and Nepal (Sobieh, 2015). Due to the rising significance of remittances in recipient developing countries, many researchers have theoretically and/or empirically analyzed the impact of remittances on the economy, obtaining results which are on average mixed.

An economic analysis of the impact of remittances on the economy of a recipient developing country is very challenging for several reasons. First, there is the issue of the duration of the analysis, viz., short-run versus long-run. A short-run analysis covers the demand-side effects of remittances on the economy - see, for example, Gonzalez and Sovilla (2014). On the other hand, a long-run analysis focuses on the supply-side effects such as an increase in real investments, human capital formation, improved factors' productivities, etc., leading to economic growth over time (see, for example, Rao and Hassan (2011)). Secondly, there is the issues of coverage of economic sectors and analyses of sizes, operational efficiency, and the quality of institutions involved in each sector. Bettin and Zazzaro (2012) show the effect of efficiency (inefficiency) of the financial sector on remittance-induced economic growth and Catrinescu et al. (2009) show that better quality of institutions 
improves the impact of remittances on economic growth. Thirdly, there are other angles which involve economic policies in the face of increased tax revenue due to remittances, an appreciation of the exchange rate, increased money supply, rising wages and prices in the non-tradeable sector, shortage of skilled labour due to emigration of domestic workers, etc. Finally, there are economic consequences of the social costs of emigration in term of family breakdown, mental health problems, and hardships for the elderly who are left behind (Acharya, 2014).

This paper deals only with the short-run economic effects of remittances. The demand-side effects of remittances in the country of origin of emigrants in a static Keynesian macroeconomic framework have been analyzed by Bhaduri and Skarstein (1996) and Gonzalez and Sovilla (2014), among others. Following on the work of Bhaduri and Skarstein (1996) and Gonzalez and Sovilla (2014), this paper proposes a model which, unlike their theoretical frameworks, introduces a remittance-induced credit expansion into the analysis. Rapoport and Docquier (2005), Gupta, Patillo and Wagh (2009) and Gani and Sharma (2013) show that a fraction of the remittances received by families and individuals is saved. It is argued in this paper that a fraction of the saved remittances must enter into financial institutions as primary deposits and that the additional primary deposits lead to an expansion in credit through the money multiplier process. With an increased money supply at a given level of demand for money, the interest rate declines in order to restore equilibrium in the monetary sector. A lower interest rate stimulates investments as marginal and near marginal projects become profitable. Simultaneously, a lower interest rate raises interest-sensitive consumption.

The incorporation of the monetary sector in the analysis of the effects of remittances has been missing in the extant macro-economic literature. Due to a concern that an increase in remittances may not lead to lower interest rates because of the rudimentary nature of the monetary sector in a recipient developing country, we check whether rising remittances are associated with lower interest rates. We report in the appendix of the paper the remittance levels and interest rates during the 2000-2015 period in four countries which have remittances as the highest percentages of their gross domestic product. The data show a significant decline in interest rates with rising remittances over time in each of the four countries.

Rapoport and Docquier (2005) argue that remittances enable the recipient families to overcome liquidity constraints and finance real investments. This positive effect of remittances on real investments is expected, as a large majority of emigrants who send remittances to their countries of origin are only temporarily out of their home countries and would like to establish businesses and/or buy capital assets to have source(s) of income on their return (see Rapoport and Docquier (2005), p. 47). In this paper, we postulate that a fraction of the saved remittances go directly to real investments. The model of the paper introduces the monetary sector and simultaneously incorporates a direct effect of remittances on investment. It analyzes the role of the monetary sector without and with remittances. It shows pairwise theoretical differences in levels of national income and illustrates their differences numerically.

The rest of the paper is divided as follows: In Section 2, a static Keynesian model is presented. The behavioral specifications and equilibrium conditions in the sectors of an economy are also given in this section. Section 3 provides the effects of 
remittance-induced credit expansion on national income and illustrates the results numerically. The summary and conclusions of the paper are given in Section 4.

\section{The Model}

\subsection{Distribution of Total Remittances}

Let the total remittances in foreign currency to a recipient developing country be $\mathrm{R}$, and $\mathrm{E}$ be the number of units of the local currency per unit of the foreign currency. RE will then be the domestic currency value of total remittances. RE will be split into consumption and saving. Consumption will be split between consumption of domestically produced goods and consumption of foreign produced goods while the saving of remittances can be distributed in any combination of increased investment, deposits, and personal hoarding by the recipients.

Assuming the marginal propensity to consume is the same among all consumers and also the same for consumption of domestically produced goods and consumption of foreign produced goods and denoting it by c, the total remittances allocated to the consumption goods are $\mathrm{c} \times \mathrm{RE}$. Assuming $\mu$ fraction of $\mathrm{cRE}$ is allocated to domestically produced goods then $c(1-\mu) \times R E$ will be spent on foreign produced goods. Obviously, the domestic currency value of saved remittances will be (1-c)RE. Let $\lambda$ be a fraction of the saved remittances that goes directly to investment, I, which means RE results in $\lambda(1-c) R E$ amount of investment. Then, $(1-\lambda)(1-c) R E$ of remittances are available as cash to be deposited with depository institutions or personally hoarded by the recipients. For the sake of simplicity, we shall assume personal hoarding to be zero, which means $(1-\lambda)(1-c) R E$ of remittances become primary deposits.

\subsection{Additional Assumptions}

1. Except for remittances as transfers, there are no other flows of capital from the foreign sector.

2. The exchange rate instantaneously adjusts to restore equilibrium in the foreign exchange market at all times.

3. The product price is fixed.

4. Investment is determined by an exogenous component and two behavioral components related to remittances and the interest rate.

5. Consumption is also sensitive to the interest rate.

6. The monetary sector of a recipient developing country consists of money and only one more financial asset which is assumed to be a bond. In response to a shock in the monetary sector the interest rate adjusts instantaneously to maintain equilibrium in the money (or bond) sector. ${ }^{1}$ 


\subsection{Behavioral Specifications}

\section{Consumption, $C$ :}

$\mathrm{C}$, in the linearized form, is:

$$
\mathrm{C}=\overline{\mathrm{C}}+\mathrm{cY}+\mathrm{c} \mu \mathrm{RE}-\mathrm{bi}, \mathrm{o}<\mathrm{c}<1, \mathrm{o}<\mu<1, \mathrm{~b}>\mathrm{o}
$$

where additional notations are:

$\overline{\mathrm{C}}=$ an exogenously determined consumption level,

$\mathrm{Y}=$ national income,

$\mathrm{i}=$ the interest rate and

$\mathrm{b}=$ the effect of $\mathrm{i}$ on $\mathrm{C}$, preceded by a negative sign.

The interest sensitive component of $\mathrm{C}$ involves expenditure on consumer durables and other big-ticket items, and consumers buy more (less) of these items if i (the borrowing cost) will fall (rise).

Investment, I, in the linearized form is:

$$
\mathrm{I}=\overline{\mathrm{I}}+\lambda \mathrm{RE}-\mathrm{gi}, \mathrm{o}<\lambda=\lambda(1-\mathrm{c}), \mathrm{g}>\mathrm{o}
$$

where

$\overline{\mathrm{I}}=$ the exogenous component of $\mathrm{I}$,

$\chi=$ the fraction of RE directly allocated to I and,

$\mathrm{g}=\mathrm{a}$ positive co-efficient that represents the interest rate sensitivity of $\mathrm{I}$; it is preceded by a minus sign.

In the industrial sector, i represents the capital cost of projects, therefore, a decline in i makes break-even and/or near break-even projects profitable while an increase in i will have the opposite effect.

\section{Foreign Sector:}

Following the conventional effects of $\mathrm{E}$ on exports and imports, to be denoted by $\mathrm{M}$, and the effect of $\mathrm{Y}$ on $\mathrm{M}$, we model export, $\mathrm{X}$, and imports, $\mathrm{M}$, as:

( $\mathrm{X}$ are in the domestic currency units and $\mathrm{M}$ are in the foreign currency units).

$$
\begin{aligned}
& X=X(E), \frac{d X}{d E}>0 \\
& M=M(Y, E), \frac{\partial M}{\partial Y}>0, \frac{\partial M}{\partial E}>0
\end{aligned}
$$




\section{Monetary Sector:}

Denoting the money demand by $\mathrm{m}^{\mathrm{d}}$, and the money supply by $\mathrm{m}^{\mathrm{s}}$, their functions are assumed to be:

The $\mathrm{m}^{\mathrm{d}}$ function, in the linearized form:

$$
m^{d}=d_{1} Y-d_{2} i, d_{1}>0, d_{2}>0
$$

That is, $\mathrm{m}^{\mathrm{d}}$ rises (falls) with income, reflecting the transaction motive for holding cash and $\mathrm{m}^{\mathrm{d}}$ falls (rises) with $\mathrm{i}$, reflecting the opportunity cost of holding money.

$\mathrm{m}^{\mathrm{s}}$, in the linearized form:

$$
\mathrm{m}^{\mathrm{s}}=\overline{\mathrm{m}}+\mathrm{sRE}, \mathrm{s}>0
$$

where $\overline{\mathrm{m}}$ is an exogenous component determined by the stance of monetary policy. The coefficient s represents two factors: (a) the fraction of RE, to be denoted by $\delta$ which is equal to $(1-\lambda)(1-c)$, and (b) the credit expansion multiplier. Assuming all deposits are identical and $\mathrm{r}$ as the required (or desired) primary reserve ratio, o > $r>1$, then the credit expansion multiplier is $\mathrm{l} / \mathrm{r}$ and $\mathrm{s}$ is $\delta / \mathrm{r}$.

\subsection{Equilibrium Conditions}

At given levels of $\mathrm{Y}$ and $\mathrm{R}$ the equilibrium in the foreign exchange sector is given by the following equation, where $\mathrm{E}^{*}$ is the equilibrium exchange rate $^{2}$.

$$
\frac{X\left(E^{*}\right)}{E^{*}}+R=M\left(Y, E^{*}\right)+c(1-\mu) R
$$

On the right hand side is the supply of the foreign currency in the recipient economy and on the left hand side is the demand for the foreign currency. It may be noted that at a given $\mathrm{X}$ and $\mathrm{M}$, it is evident from equation (7) that an increase in $\mathrm{R}$ must lower $\mathrm{E}$ to restore equilibrium in the foreign exchange sector. This will represent an appreciation of the local currency in terms of the foreign currency.

Rearranging $\mathrm{E}^{*}$ and multiplying throughout with $\mathrm{E}^{*}$ :

$$
X\left(E^{*}\right)-M\left(Y, E^{*}\right) E^{*}=-R E^{*}(1-c(1-\mu))
$$

At given levels of $\mathrm{Y}, \mathrm{R}$ and $\mathrm{E}$, the equality of money demanded and money supplied determines the equilibrium level of the interest rate (denoted by $\mathrm{i}^{*}$ ) as given below:

$$
\begin{aligned}
& \mathrm{m}^{\mathrm{d}}=\mathrm{m}^{\mathrm{s}} \\
& \mathrm{d}_{1} \mathrm{Y}-\mathrm{d}_{2} \mathrm{i}^{*}=\bar{m}+\mathrm{sRE}
\end{aligned}
$$

Solving for $\mathrm{i}^{*}$ : 


$$
\mathrm{i}^{*}=\frac{\mathrm{d}_{1} \mathrm{Y}-\overline{\mathrm{m}}-\mathrm{sRE}}{\mathrm{d}_{2}}
$$

This equation indicates that keeping $\mathrm{Y}$ and $\overline{\mathrm{m}}$ constant, if RE will increase, $\mathrm{i}^{*}$ will decline and the extent of the decline depends on $s$ and $d_{2}$. A higher $s$, with $d_{2}$ constant, reduces $i^{*}$ more, and a lower $\mathrm{d}_{2}$, with $\mathrm{s}$ constant, also reduces $\mathrm{i}^{*}$ more.

Finally, an equilibrium in the aggregate economy, which must embody the equilibrium conditions in the foreign exchange sector and the monetary sector, requires that the supply of income, $\mathrm{Y}$, is equal to the demand for income, that is:

$$
\mathrm{Y}^{*}=\mathrm{C}+\mathrm{I}+\mathrm{X}-\mathrm{ME}^{*}
$$

Using equations (1), (2), (7)' and (9) in equation (10), we get:

$$
\begin{aligned}
Y^{*}=\bar{C}+ & c Y^{*}+c \mu R E^{*}-b\left\{\frac{d_{1} Y^{*}-\bar{m}-s R E^{*}}{d_{2}}\right\}+\bar{I}+\lambda R E^{*} \\
- & g\left\{\frac{d_{1} Y^{*}-\bar{m}-s R E^{*}}{d_{2}}\right\}-\operatorname{RE}^{*}(1-c(1-\mu))
\end{aligned}
$$

\section{Effects of Remittances on National Income}

In equation (11), collecting all the terms involving $\mathrm{Y}^{*}$ and collecting all the terms involving $\mathrm{RE}^{*}$, by simplifying and rearranging, we get:

$$
Y^{*}=\frac{\bar{C}+\bar{I}+\frac{\bar{m}}{d_{2}}(b+g)}{(1-c)+\frac{d_{1}}{d_{2}}(b+g)}-R E^{*}\left\{\frac{(1-c)-\lambda-\frac{s}{d_{2}}(b+g)}{(1-c)+\frac{d_{1}}{d_{2}}(b+g)}\right\}
$$

In equation (12) the parameters that relate to the monetary sector are: $d_{1}=$ the transaction motive coefficient, $d_{2}=$ the coefficient of the interest rate in the money demand function, $\delta=$ the fraction of RE which become primary deposits, $r$ $=$ the desired (or required) primary reserve ratio of domestic depository institutions, $b=$ the coefficient of the interest rate in consumption and $g=$ the coefficient of the interest rate in investment, and $\bar{m}$ (which represents the supply of money determined by the stance of monetary policy). These parameters appear in the numerator and the denominator of each of the two terms on the right hand side of equation (12). Obviously, the exact effects of the monetary sector on national income depend on its numerical values and without creditable estimates of the parameters and $\bar{m}$, those exact effects cannot be determined. But we present some theoretical possibilities, with some illustrative numerical values of exogenous variables and parameters, below.

\section{Case 1}

Suppose foreign remittances are zero and there is no monetary sector in the recipient economy. Then, the equilibrium national income, $\mathrm{Y}^{*}$, in equation (12), becomes: 


$$
\mathrm{Y}^{*}=\frac{\overline{\mathrm{C}}+\overline{\mathrm{I}}}{1-\mathrm{C}}
$$

Denoting a local currency unit as L\$ and assuming $\overline{\mathrm{C}}=\mathrm{L} \$ 50$ billion, $\overline{\mathrm{I}}=\mathrm{L} \$ 10$ billion and $\mathrm{c}=80 \%$, the equilibrium level of $\mathrm{Y}$ is $\mathrm{L} \$ 300$ billion.

\section{Case 2}

Assuming that remittances are still equal to zero and introducing the monetary sector as specified in the model, the equilibrium level of $\mathrm{Y}$ is given by the first term of equation (12). The parameters of the monetary sectors appear both in the numerator and the denominator and since $\bar{m}, d_{1}, d_{2}, b$ and $g$ are all positive, the overall effect of the monetary sector in the static short-run Keynesian framework appears to be ambiguous.

Focusing on the denominator, we see that an increase (a decrease) in $\mathrm{Y}$ raises (reduces) the money demand through the transaction motive which, given the fixed quantity of the money supply, must raise (lower) the interest rate to restore equilibrium in the monetary sector. The increase (decrease) in the equilibrium level of the interest rate, in turn, affects consumption and investment through interest sensitivity coefficients b and g respectively. As a consequence, the amplifying effect of an exogenous shock to income is reduced. Similarly, a lower $\mathrm{d}_{2}$ also reduces the amplifying effect of an exogenous shock to income as it will require larger movements in the interest rate to restore equilibrium in the monetary sector in the wake of increasing (shrinking) income.

In the numerator of the first term, $\overline{\mathrm{m}}$ plays a critical role in determining equilibrium income. Given that the parameters of the monetary sector reduces the size of the multiplier of an exogenous shock to national income, $\bar{m}$ has to be high enough for the monetary sector to have a favorable effect. The break-even level of $\overline{\mathrm{m}}$ in this context is given $\mathrm{by}^{3},{ }^{4}$

$$
\overline{\mathrm{m}}=\left(\frac{\overline{\mathrm{C}}+\overline{\mathrm{I}}}{1-\mathrm{C}}\right) \mathrm{d}_{1}
$$

Suppose $\mathrm{d}_{1}=0.4$ (which means that an increase in income by one L $\$$ increases transaction balances by L $\$ 0.4$ ), $\mathrm{d}_{2}=6$ (which means that one percentage point increase (decrease) in the interest rate will reduce (increase) the money demand by $\mathrm{L} \$ 6$ billion), $\mathrm{b}=.02$ (which means that a percentage point increase (decrease) in the interest rate results in a decrease (increase) in consumption by L $\$ 0.02$ billion), $g=$ 0.7 (which means that a percentage point increase (decrease) in the interest rate reduces (increases) investment by $\mathrm{L} \$ 0.7$ billion) and $\overline{\mathrm{m}}=\mathrm{L} \$ 150$ billion. Then

$$
\mathrm{Y}^{\mathrm{x}}=\frac{50+10+\frac{150}{6}(.02+.7)}{(1-.8)+.4 / 6(.02+.7)}=\mathrm{L} \$ 314.49 \text { billion }
$$

Given the numerical specification of the model, the contribution of the monetary sector, without remittances, is represented by L $\$ 14.49$ billion. 
An uninteresting (unrealistic) variation of this case is a situation where the monetary sector exists but the interest rate does not affect investment and consumption (that is $\mathrm{g}=\mathrm{b}=\mathrm{o}$ ). In this situation, the monetary sector has no effect on the economy.

\section{Case 3}

Remittances, $\mathrm{R}>\mathrm{o}$ but the monetary sector does not exist. Then, from equation (12), the equilibrium level of $\mathrm{Y}$ is:

$$
\mathrm{Y}^{*}=\frac{\overline{\mathrm{C}}+\overline{\mathrm{I}}}{1-c}-\mathrm{RE}^{*}+\frac{\tilde{\lambda}}{1-c} \mathrm{RE}^{*}
$$

The second term on the right side of this equation indicates that a $\mathrm{L} \$$ worth of remittances reduces the equilibrium level of national income by a $\mathrm{L} \$$. This is the main result of the Gonzalez and Sovilla (2014) paper which derives the remittance multiplier ( -1$)$ theorem. The third term is positive as it arises from a direct positive effect of remittances on investment, which, in turn, raises the size of the remittance multiplier.

If the fraction of remittances allocated to investment were to rise to $(1-c)$, then the overall effect of remittances on income will be zero as can be seen from equation (15). However, as some portion of remittances is expected to be held in cash or deposits, the value of $\tilde{\lambda}$ as high as $(1-\mathrm{c})$ is very unlikely.

As a numerical illustration, suppose $\mathrm{R}=\$ 6$ billion $\mathrm{E}^{*}=10$ units of $\mathrm{L} \$$ per unit of the foreign currency: $\mathrm{RE}^{*}=\mathrm{L} \$ 60$ billion and $\tilde{\lambda}=.05$. Then,

$$
\mathrm{Y}^{*}=300-60+\frac{.05}{0.2} \times 60=\mathrm{L} \$ 255 \text { billion }
$$

\section{Case 4}

$\mathrm{R}>\mathrm{o}$ and the monetary sector exists, then the second term captures the remittance-induced expansion of credit which is given by $\mathrm{s} / \mathrm{d}_{2}(\mathrm{~b}+\mathrm{g})$ where $s=$ $\delta / r$ ( $\delta=$ the fraction of remittances deposited in depository institutions, $\mathrm{r}=$ the desired (or required) primary reserve ratio, giving the money multiplier of $1 / \mathrm{r}$ ). A lower $d_{2}$ raises the expansionary effect of the credit expansion because a lower $d_{2}$ means that a decline in interest rates will be larger. In this situation, larger magnitudes of $b$ and $g$ will be favorable for the economy.

As has been noted in Case 3, remittances without the monetary sector lead to lower income except in an extreme situation where $\tilde{\lambda}=1-c$. The presence of a remittances-induced credit expansion improves national income and depending on the sizes of $\delta$ and $\mathrm{r}$, given the same values of $\mathrm{d}_{2}$, b and g as before, the overall effect of remittances on national income can be positive ${ }^{5}$. This is what is assumed in a numerical illustration of this case below. 
Continue to assume the same numerical magnitudes of $\bar{C}, \bar{I}, c, \tilde{\lambda}, \bar{m}, d_{1}, d_{2}$, b, $\mathrm{g}, \mathrm{R}$ and $\mathrm{E}^{*}$ as before and add $\delta=0.15$ and $\mathrm{r}=10 \%$. With $\mathrm{r}=10 \%$, the credit expansion multiplier is $10 . \mathrm{Y}^{*}$ from equation (12) is:

$$
\begin{aligned}
\mathrm{Y}^{*} & =314.49-60\left[\frac{(1-.8)-.05-\frac{.15 \times 10}{6}(.02+.7)}{.2480}\right] \\
& =314.49+7.258 \\
& =\mathrm{L} \$ 321.748 \text { billion }
\end{aligned}
$$

Compared with the results in Case 3, it appears that the overall contribution of the monetary sector to the economy of a recipient country is L\$ 66.748 billion and with this positive effect on the national income, the remittances-induced expansion plays a major role.

Finally, we need to emphasize that the numerical examples given in the analysis are only for illustrative purposes as we do not have empirical estimates of parameters and exogenous variables of the model of a recipient country's economy. Obviously, different numerical magnitudes than those assumed in this paper are likely to lead to different numerical results.

\section{Summary and Conclusions}

It has been argued in this paper that there is a portion of remittances sent by emigrants to their home countries which is saved. This paper introduced two uses of the saved remittances. First, it introduced a direct effect of saved remittances on investment and argued why this direct effect on investment should be expected. Second, and more importantly, it introduced the monetary sector into the macroeconomic analysis of remittances on the basis of the argument that a portion of saved remittances would enter into the banking sector as primary deposits, resulting in an expansion of credit through the credit expansion multiplier process. An increase in the money supply, all else being the same, is shown to lead to a decline in the equilibrium level of the interest rate. This decline in the interest rate results in stimulating both investment and consumption.

The paper proposed a standard static Keynesian model, with the aforementioned two uses of saved remittances, and derived the equilibrium level of national income of a recipient country's economy. The results of the paper are analyzed in different situations in order to focus on the contributions to the economy of the direct effect of remittances on investment and the effects of remittanceinduced credit expansion on consumption and investment expenditures.

\section{Endnotes}

${ }^{1}$ The monetary sector is modelled in the traditional Keynesian fashion. It can be expanded by introducing more than two financial assets but that will not change the basic thrust of our argument about the negative effect of remittances on the interest rate. 
2 To make the model tractable and to avoid dealing with the international capital flows and the expected future spot exchange through the Fisher open parity, we omit the effect of the interest rate on the current spot exchange rate.

${ }^{3}$ The existence of the monetary sector is expected to have some strong positive effects on investment and consumption expenditures due to the monetization of the economy and the availability of credit. These direct effects are not considered in the model of this paper in order to focus on the effects of the remittance-induced reduction in the interest rate on expenditures.

${ }^{4}$ The break-even level of $\bar{m}$ is $L \$ 120$ billion. At this level of $\bar{m}$, the monetary sector will have no effect on national income while at $\overline{\mathrm{m}}>\mathrm{L} \$ 120$ billion, the monetary sector has a positive effect on income.

${ }^{5}$ Given values of $\mathrm{c}, \tilde{\lambda}, \delta, \mathrm{r}, \mathrm{d}_{2}$, b and $\mathrm{g}$, if $-\left\{1-\mathrm{c}-\tilde{\lambda}-\frac{\mathrm{s}}{\mathrm{d}_{2}}(\mathrm{~b}+\mathrm{g})\right\}>\mathrm{o}$, the remittances will expand national income, otherwise they will not do so.

\section{References}

Acharya, R. 2014. A faulty lifeline, Kathmandu Post, September 4.

Bettin, G. and Zazzaro, A. 2012. Remittances and financial development: Substitutes or complements in economic growth?” Bulletin of Economic Research, 64(1): 509-536.

Bhaduri, A. and Skarstein, R. 1996. Short period macroeconomics aspects of foreign aid, Cambridge Journal of Economics, 1996 (20): 195-206.

Catrinescu, N., Leon-Ledesma, M., Piracha, M. and Quillin, B. 2009. Remittances, institutions and economic growth, World Development, 37(1): 81-92.

Edwards, A.C. and Ureta, M. 2003. International migration, remittances, and schooling: Evidence from El Salvador, Journal of Development Economics, 72(2): 429-446.

Gani, A. and Sharma, B. 2013. Remittances and credit provided by the banking sector in developing countries, International Review of Business Research Papers, 4(3): 85-98.

Gonzalez, L.A.A. and Sovilla, B. 2014. The remittance multiplier (-1) theorem, Journal of Post Keynesian Economics, 36(3): 541-554.

Gupta, S., Patilla, C.A., and Wagh, S. 2009. Effect of remittances on poverty and financial development in Sub-Saharan Africa, World Development, 39(1): 104-124.

Rao, B.B. and Hassan, G.M. 2012. Are the direct and indirect growth effects of remittances significant?” The World Economy, 35(3): 351-372.

Rapoport, H. and Docquier, F. 2006. The economics of migrants’ remittances.” In Kolm, S. and Mercier, J. (Eds.). Handbook of Economics of Giving, Altruism and Reciprocity, Amsterdam, North Holland, 1138-1195.

World Bank. 2014. Migration and Development: Recent Developments and Outlooks. Washington DC: World Bank Group. 


\section{Appendix: Interest Rates and Remittances (US \$ million)*}

\begin{tabular}{|l|l|l|l|l|l|l|l|l|}
\hline & \multicolumn{2}{|l|}{ Kyrgyz Republic } & \multicolumn{2}{|c|}{ Tajikistan } & \multicolumn{2}{|c|}{ Tonga } & \multicolumn{2}{c|}{ Moldova } \\
\hline Year & i & Rem & i & Rem & i & Rem & i & Rem \\
\hline 2000 & 10.6 & 9 & 1.3 & -- & 5.5 & -- & 24.9 & 179 \\
2001 & 7.7 & 11 & 5.2 & -- & 5.4 & 53 & 20.9 & 243 \\
\hline 2002 & 2.8 & 37 & 9.5 & 79 & 5.5 & 66 & 14.2 & 324 \\
\hline 2003 & 2.1 & 78 & 9.8 & 146 & 5.5 & 66 & 14.2 & 324 \\
2004 & 1.5 & 189 & 10.2 & 252 & 5.5 & 69 & 15.1 & 705 \\
\hline 2005 & 1.7 & 313 & 10.2 & 467 & 5.9 & 69 & 13.2 & 915 \\
\hline 2006 & 1.6 & 473 & 9.5 & 1019 & 6.5 & 79 & 11.9 & 1176 \\
2007 & 3.0 & 704 & 11.0 & 1691 & 6.7 & 101 & 15.01 & 1491 \\
\hline 2008 & 2.6 & 1223 & 9.4 & 2544 & 6.5 & 94 & 17.9 & 1888 \\
\hline 2009 & 3.2 & 982 & 7.6 & 1748 & 5.2 & 72 & 14.9 & 1199 \\
2010 & 2.0 & 1266 & 8.6 & 2306 & 4.0 & 77 & 7.7 & 1351 \\
\hline 2011 & 2.3 & 1709 & 8.2 & 3060 & 3.9 & 79 & 7.6 & 1813 \\
\hline 2012 & 2.6 & 2031 & 7.7 & 3626 & 2.8 & 118 & 7.6 & 1986 \\
2013 & 2.5 & 2278 & 6.5 & 4219 & 2.7 & 121 & 7.2 & 2092 \\
\hline 2014 & 2.7 & 2243 & 5.5 & 3384 & 2.8 & 118 & 5.7 & 2084 \\
\hline 2015 & 2.7 & 1688 & 4.2 & 2259 & 3.1 & 118 & 11.9 & 1533 \\
\hline
\end{tabular}

*Interest rate $\mathrm{i}$ is a deposit rate in depository institutions.

Sources: IMF, International Financial Data. At www.data.worldbank.org and Remittances Data available at https://www.worldbank.org/en/topic/migration-remittancesdiasporaissue/brief/ migration-remittances-com. Retrieved on January 28, 2017. 